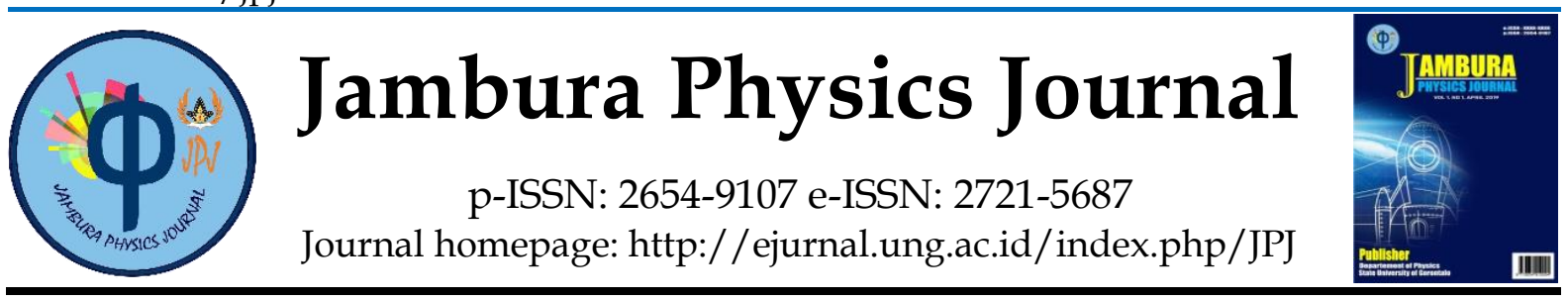

\title{
PROFILE OF STUDENTS ANALYTICAL THINKING SKILLS IN LEARNING STYLE FOR COMPLETING SUBSTANCE PRESSURE PROBLEMS
}

\author{
Wirawan Fadly ${ }^{1}$ \\ ${ }^{1}$ Science Tadris Department, IAIN Ponorogo. Jalan Pramuka No.156, Siman, Ponorogo 63471, Indonesia \\ Email: wira1fadly@iainponorogo.ac.id
}

Received: 30 January 2021. Accepted: 27 April 2021. Published: 30 April 2021.

\author{
ARTICLE INFO \\ Keywords: \\ Analytical thinking; \\ Learning style; \\ Substance pressure \\ problems \\ How to cite: \\ Fadly, W. (2021). Profile \\ of Students Analytical \\ Thinking Skills in \\ Learning Style for \\ Completing Substance \\ Pressure Problems. \\ Jambura Physics Journal, \\ 3(1), 1-15. \\ DOI: \\ https://doi.org.10.34312 \\ /jpj.v3i1.9792
}

\begin{abstract}
The skill to think analytically is an important skill for students to have, where the skill to think analytically helps students solve problems in science lessons that require an analytical skill to solve them. The research method is qualitative with a naturalistic design. This research was conducted at some Junior High schools in Ponorogo using the purposive sampling technique. Data were collected using in-depth interviews, observation, and documentation, then analyzed using quantitative descriptive and qualitative descriptive. This study aims to determine the profile of students' analytical thinking skills in solving problem-based problems in the grade $8^{\text {th }}$ at pressure material and determine the pattern of its relationship with scientific exploration. The results showed that: 1) the profile of the analytical thinking skill in terms of the learning styles of students, namely the visual style subjects intend to explain what is known through the direct explanation in more detail, the audiovisual subjects are more likely to form simpler patterns with reasoning patterns generalization and on kinesthetic subjects tend to apply different (unique) concepts, but still have a relationship with the problem, 2) the pattern of the relationship between analytical thinking skills and learning styles, namely the exploration of science, which includes aspects of experience, reasoning, modalities, and the mindset of students. Through the results of this study, it is hoped that it can provide theoretical and practical insights for educators in determining approaches and strategies for achieving science analytical competence according to students' learning styles at school.
\end{abstract}




\section{Introduction}

Analytical thinking is a cognitive skill at the highest level after remembering, understanding concepts, and applying concepts. In Indonesia, the average analytical the thinking skill of junior secondary students is still in the low category. In learning, students have not been invited to play an active role during the learning process and are also not used to solving problem-based problems in everyday life. Days that should be able to be a tool to hone the analytical thinking skills of students. Habit in the learning process will make students accustomed to facing questions in the form of analysis so that when faced with complex questions, students will be able to solve them well (Dierks et al., 2016; Taleb \& Chadwick, 2016).

The analytical thinking skill of each student is different from one another. It depends on how students' readiness is in receiving student material, processing, and absorbing subject matter. The habits of learners in receiving, absorbing, and managing information received are called learning styles. Learning styles include cognitive, affective, and physiological characteristics that serve as relatively stable indicators of how learners interact and respond to the learning environment (Al-Balushi \& Coll, 2013). Differences in learning styles in students can describe the differences in students in receiving lessons even though in the same room and the same teacher (Jones et al., 2013; Sari, 2014; Wahyuni, 2017).

A teacher who knows the difference, difficulties, and obstacles students face, will choose and adjust the right learning, of course, accompanied by adjusting the teacher's learning style with the students' learning style. However, if this is not done, it will result in the science teaching and learning process not being optimal, which will lead to higher-order thinking skills, especially the students' analytical thinking, which will not develop properly. Increasing the teaching and learning process effectiveness is necessary to conduct in-depth research on student learning (Lopez \& Tancinco, 2016). Learning style is the preferred way for someone to think, process, and understand information.

A person's learning style is a combination of how a person absorbs, and then organizes and processes information. Student learning styles include visual, auditory, or kinesthetic (VAK) learning styles(Thomas, 2013). This learning style's characteristics are visual students learn through what they see, auditory students learn through what they hear, and kinesthetic students learn through movement and touch. Even though every student has a learning style, but most students tend to have one learning style, and kinesthetic students learn through movement and touch. Even though every student has a learning style, most students tend to have one learning style and kinesthetic students learn through movement and touch. Even though every student has a learning style, most students tend to have one learning style.

Problem-based questions are science questions that often occur and are often encountered by students in everyday life. Meanwhile, not all questions made were problem-based questions. Therefore, the question will be a problem if the question contains descriptive elements in the delivery of the language and has an element of analysis in the use of rules/laws used in solving it(Cano et al., 2014). The linkage between analytical thinking skills and learners' learning styles becomes a bridge to learning goals. Several new aspects are found in this connection, namely reasoning, experience, thought patterns, and mobility. This aspect bridges the skill to think 
Fadly, W./ Jambura Physics Journal (2021) Vol. 3 (1): 1-15

analytically and learning styles and is supported by other aspects (Gustiati, 2017; Marini, 2014). It is known that there is a mutually supportive relationship for the formation of scientific exploration, formation of scientific exploration, namely aspects of reasoning, modality, experience, and mindset. This study aims to determine the profile of students' analytical thinking skills in terms of learning styles and how the patterns are related to the formation of scientific exploration.

\section{Methode}

This research is qualitative research with a naturalistic design. The research was conducted in several junior high schools (SMP/MTs) in Ponorogo. The research sample originally consisted of 15 students who were representatives of each school(Fraenkel \& Wallen, 2012; Moleong \& Surjaman, 1991). The sample was taken by purposive sampling with the sampling criteria were students of grade 8 who had the highest scores in each school. Classification of learning styles is carried out by giving a questionnaire to the 15 students. Because there is 1 learning style consisting of 3 students, then only three representatives are determined for each learning style with the same proportion. The number that is more than three is taken, which has the highest 3 scores, resulting in 3 visual subjects, 3 audiovisual subjects, and 3 kinesthetic subjects.

Each sample is then given a test description and pictorial test on the Pressure material. The questions made are adjusted to the indicators contained in the skill to think analytically. The indicator of analytical thinking used as a reference is an indicator of analytical thinking(Dierks et al., 2016; Lopez \& Tancinco, 2016). The indicators of analytical thinking are (1) identifying a problem, (2) finding and knowing relationship patterns carefully, (3) identifying and evaluating various errors, (4) concluding the main idea, which in each indicator also contains the skill of scientific processing.

From the test results, the answers are then identified based on their uniqueness and depth of discussion, confirmed using in-depth interviews or in-depth interviews with the subject conducted directly. The data obtained were then categorized, reduced, and analyzed using quantitative descriptive and qualitative descriptive.

Table 1. Indicator Table of Analytical Thinking Skill

\begin{tabular}{|c|c|c|}
\hline No. & Indicator & Information \\
\hline 1. & Identifying a problem & $\begin{array}{l}\text { - Observe the problem formulation and find out the } \\
\text { keywords of the problem statement to know the focus } \\
\text { of the question request } \\
\text { - Arrange data sequentially and clearly through tables, } \\
\text { graphs, or other forms. } \\
\text { - Find out valid and invalid data or information }\end{array}$ \\
\hline 2. & $\begin{array}{l}\text { Finding and Knowing } \\
\text { the pattern of } \\
\text { relationships carefully }\end{array}$ & $\begin{array}{l}\text { - Determine the pattern of each concept/part. } \\
\text { - Making relationships that are still one concept } \\
\text { - It contains one general concept and confronts the } \\
\text { concept into problems. }\end{array}$ \\
\hline
\end{tabular}


Fadly, W./ Jambura Physics Journal (2021) Vol. 3 (1): 1-15

\begin{tabular}{|c|c|c|}
\hline 3. & $\begin{array}{l}\text { Identifying and } \\
\text { evaluating various } \\
\text { errors }\end{array}$ & $\begin{array}{l}\text { - Knowing conscious what mistakes have been made } \\
\text { during the procedure } \\
\text { - Make corrections for these mistakes with reliable } \\
\text { solutions. }\end{array}$ \\
\hline 4, & $\begin{array}{l}\text { Summing up the main } \\
\text { idea }\end{array}$ & $\begin{array}{l}\text { - Express the conceptual similarities of the problem at } \\
\text { hand } \\
\text { - After knowing the similarity of the } \\
\text { problems/problems faced, it is formed into a general } \\
\text { concept } \\
\text { - And the final result is to draw the main concept/idea } \\
\text { of the problems. }\end{array}$ \\
\hline
\end{tabular}

\section{Result and Discussion}

Based on the results of observations and field data analysis, the profile of the skill to think analytically in solving problems based on the VAK learning style (Visual, Audiovisual, and Kinesthetic) can be described as follows.

\subsection{Profile of Students' Analytical Thinking Skill Visual Learning Style}

The following is an excerpt from the visual subject interview 1 (SV1):

SV1: In my opinion, it is more tired to use shoes with high heels because the cross-sectional area is smaller than shoes with flat bottoms, so if the cross-sectional area is small, the resulting pressure will be greater so that it will cause you to tire more quickly when wearing it. The pressure will also adjust to the person's weight, or it can be interpreted as body weight such as the pressure and heel of the shoe as a cross-sectional area so that the resulting pressure is the force divided by the cross-sectional area.

Based on the interview excerpt above, SV1 states that when a person uses shoes with heels, the pressure they feel will be following their respective bodyweight. In this case, the subject equates body weight with compressive force, and the heel of the shoe is compared to the cross-sectional area, so the pressure is large. Besides formula, weight is divided by the heel area of the shoe you are wearing. So it can be seen that the amount of pressure adjusts to the value someone has. Following the equation for solid pressure, that pressure is the amount of force divided by the cross-sectional area of an object or written as $\mathrm{P}=\mathrm{F} / \mathrm{A}$, which means that the amount of pressure is directly proportional to the applied compressive force.

Supported by visual subject statement 2 (SV2):

SV2: In my opinion, I get more tired when using shoes with heels because the cross-sectional area is narrow, so it will generate much pressure because the pressure will be greater the narrower the cross-sectional area. Because the mass is great, the pressure from the bodyweight down will also be greater, so you will feel a great sense of fatigue too.

Based on the results of tests and interviews with SV2, it is known that when a person wears shoes with heels, the resulting pressure is greater, and makes the feet feel tired. This is due to the small cross-sectional area of the shoes and causes the pressure to be even greater. This is because the pressure is inversely proportional to the cross-sectional area. When the cross-sectional area is small, the pressure will be greater according to the equation for solid pressure, namely, $\mathrm{P}=\mathrm{F} / \mathrm{A}$, which is for the 
Fadly, W./ Jambura Physics Journal (2021) Vol. 3 (1): 1-15

same force, the smaller the cross-sectional area of an object, the pressure will be the big one. From the answers that the subject gives, there is a relationship between the answers and the theory of pressure on solids, so it can be said that subject 2 has good identifying skills as the basis of analytical thinking skills.

In more detail, at the initial stage of identifying a problem, the visual subject carries out the activity of distinguishing important parts of the problem into parts that are still one unit and making connections between these parts with a more detailed explanation. Visual subjects tend to think inductively, namely looking for reasons or causes of a problem in the form of a general description. The general form of inductive thinking is a generalization with a limited scope. Visual subjects tend to determine the focus of the problem that is on the problem through understanding the questions the subject read. that what is meant by understanding is the skill to capture meanings such as being able to express a material that is presented in another form that can be understood, able to provide interpretations, and be able to classify them.

The visual subject also labels parts that have been differentiated by separating what is known in questions and asking the questions. One indicator of the skill to analyze is when a person receives information, then analyzes and shares the information or structures it into smaller sections to recognize the relationship patterns in the information received. So the labeling carried out by the subject is the same as structuring information into smaller parts so that the three subjects managed to find the right relationship pattern (Winarti, 2015). In identifying and evaluating various errors, the visual subject is more likely to solve the problems faced by using concepts, laws, and theories that are general and then directly confronted with the problems, so that in solving them, the visual subject will be easier and simpler.

Various problem-solving strategies can be taught to students to provide an experience to take advantage of them when facing a variety of problems. They must also be encouraged to make solutions to a problem they are facing appropriately. In concluding the main idea that the visual subject applies a law that he knows to a problem, and the visual subject tends to give the same answer, meaning that the three subjects have understood and understood the application of the law is a problem so that it can be stated that the visual subject can conclude the main idea of a problemspecific or specific problem. Understanding an idea, ideas, and concepts requires a fairly high skill of generalization and abstraction.

\subsection{Profile of Students' Analytical Thinking Skill Audiovisual Learning Style}

The following is an excerpt from the audiovisual subject interview 1 (SA1):

\section{SA1: In my opinion, I get more tired when wearing shoes with high heels because the smaller} the cross-sectional area, the greater the pressure, so the fatigue will also be greater.

Based on the interview results on SA1 it is known that when wearing shoes with heels, the resulting pressure will be greater so that it makes the feet feel tired. This is because the cross-sectional area of the shoes is small to cause the heel to become larger and support the body's load. According to the equation $\mathrm{P}=\mathrm{F} / \mathrm{A}$, the amount of pressure is inversely proportional to the cross-sectional area. The smaller the crosssectional area of an object, the greater the pressure. From the answers given SA1, there is a relationship between the answers and the theory of pressure on solids, so it can be said that SA1 has good identifying skills using only general stress concepts. 
Fadly, W./ Jambura Physics Journal (2021) Vol. 3 (1): 1-15

Supported by audiovisual subject interview excerpt 2 (SA2):

SA2: In my opinion, I get more tired when using shoes with high heels because the resulting pressure is also greater, because the smaller the area of a cross-section, the greater the resulting pressure. So when we wear shoes with flat heels, the heeled shoes' crosssectional area is smaller, resulting in greater pressure.

Hail of the SA2 interview stated that when someone uses shoes with heels, their pressure will be greater, because the cross-sectional area is small, so the pressure they feel will be even greater. By the equation on the pressure of solids, the pressure is the amount of force divided by the cross-sectional area of an object or written as P = F/ A. So it is known that SA2 can identify well by connecting the problem with the pressure equation in general (generalization).

At the problem identification stage, audiovisual learning style students are more likely to form relationship patterns through speaking or storytelling activities. Audiovisual subjects tend to have a deductive mindset, meaning that they focus on general will then be drawn on specific information. In applying deductive reasoning, the truth of a concept or statement is obtained as a logical consequence of the previous truth, so that the relationship between concepts or a statement is consistent (Permana \& Sumarmo, 2007).

At the stage of determining the focus of students' problems with audiovisual learning styles, determining the focus of the problem through understanding the questions they get, in general, audiovisual students determine the focus of the problem using the inductive method, which means making conclusions in general from the specific information that students have understood. The general form of inductive thinking is a generalization with a limited scope, so it is known that the subject makes generalizations before determining the problem's focus(Nugraha et al., 2017; Shen et al., 2015). At the stage of identifying and evaluating various errors, students in audiovisual learning styles tend to do it by checking the suit skill between the calculations' results and the accuracy of the answers from the images on the questions.

Checking what has been done starting from the initial and final work results will reduce various mistakes, and checking will make students' answers closer to the truth by seeing their suit skill with the questions given. So it is known that the subject generalizes before determining the focus of the problem(Nugraha et al., 2017). At the stage of identifying and evaluating various errors, students in audiovisual learning styles tend to do it by checking the suit skill between the calculations' results and the accuracy of the answers from the images on the questions.

When finding solutions to problems, students with an audiovisual learning style tend to solve them with meaningful solution methods, meaning that the audiovisual subject does and does things that he does not know to get new information. Solving a problem is considered as an approach, solving meaningful problems, namely to find solutions to problems students must use things that have been previously learned, then carry out the process of developing new understandings so that they will emerge and create a new solution strategy. In concluding the main idea the audiovisual subject does by categorizing a problem into its appropriate (special) parts. The audiovisual subject will be able to make a general conclusion from a particular 
Fadly, W./ Jambura Physics Journal (2021) Vol. 3 (1): 1-15

the problem, which is part of the activity of analyzing a problem. Analytical skill is the skill to detail, group a problem into smaller parts, and understand these small parts (Henderson et al., 2015).

\subsection{Profile of Students' Analytical Thinking Skill Kinesthetic Learning Style}

The following is an excerpt from the interview of the kinesthetic subject 1 (SK1):

SK1: I get more tired when wearing heels. When wearing shoes with heels, the bodyweight will be supported by the soles of the front feet because when wearing heels, our feet will experience a tilt so that only the forefoot supports the weight of the body, so that the soles of the forefoots will get much pressure from the load. This is supported, and when the burden of the person using the high heeled shoe, the pressure will adjust to the load of the person using it so that it will remain directly proportional to the feeling of fatigue that is felt.

Based on the results of the interview with SK1, it can be seen that when someone wears shoes with heels, they will feel more tired than flat shoes, because when wearing shoes with heels, the feet will be on an oblique position with the sole of the forefoot being lower than the heel of the foot. The load will focus on the forefoot's soles and make the feet feel tired because the pressure exerted by the body is focused on the soles of the feet or not evenly distributed.

In the science concept, the pressure on the feet is not evenly distributed, the body load as the applied compressive force $(\mathrm{F})$ and the heel of the shoe as the cross-sectional area $(\mathrm{A})$. So that because the compressive force exerted only focuses on the soles of the forefoot, not on the heel / cross-sectional area, the value of the cross-sectional area of the heel will be small, resulting in greater pressure, because the amount of pressure is inversely proportional to the area of the compressed plane, at the magnitude of the force. The same, the smaller the area of the compressive plane, the greater the pressure. The statement proves that SK1 can identify a problem, seen from the subject's answer, which has explained a basic reason, and the subject can identify a problem and naturally describe the problem.

Supported by the kinesthetic subject statement 2 (SK2):

SK2: You will be more tired when using shoes with heels because the bodyweight is not supported evenly on the feet, the soles of the forefoots are lower than the heels so that the body's weight will rest on the heels and make the feet more tired. The person's burden will rest on the heel so that the leg muscles will feel cramped and tired. For example, the weight is like a force, and the heel of the shoe is the cross-sectional area so that the resulting pressure is the force divided by the cross-sectional area. And the smaller the cross-sectional area, the resulting pressure will be greater.

The interview results above stated that wearing shoes with heels will be more tired than wearing flat-bottomed shoes, and this is because when wearing high-heeled shoes, the weight of the body that presses the feet is not evenly distributed so that it will put more pressure on the heels. Therefore feet will feel tired more easily. The concept of body load pressure is likened to the compressive force $(\mathrm{F})$, and the heel of the shoe is the cross-sectional area (A). So the pressure obtained (fatigue) will be greater, according to the equation $\mathrm{P}=\mathrm{F} / \mathrm{A}$, that the amount of pressure obtained by 
Fadly, W./ Jambura Physics Journal (2021) Vol. 3 (1): 1-15

an object will be inversely proportional to the cross-sectional area, so the smaller the cross-sectional area of an object will result in the greater pressure.

In the early stages of identifying a problem, the kinesthetic subject tends to realize scientific concepts into a problem through focused observation), so that they will be able to build an analytical mindset in the identification stage to solve a problem. The human skill to categorize, distinguish and identify limited objects is the building block of thinking and is the basis for higher mental processes and is needed in solving problems. Distinguishing the important parts of the question into parts that are still one unit and make connections between these parts, that analysis can also form students who can distinguish fact information from opinions (reality from imagination) or combine the two (Winarni et al., 2016). In addition to this, the kinetic subject maximizes the answers asked by detailing a general concept (in the form of a pressure equation) and connecting it to a more specific problem. It will help maximize the identification process in solving a problem. Analytical thinking patterns emphasize solving material into more specific parts, detecting the relationships between them, and combining them into a solution or solution.

Kinesthetic subjects can find relationship patterns carefully. Visual subjects tend to determine the focus of problems in questions by understanding the concept in general. The main objective of science education is to help students develop higherorder thinking skills to face challenges in everyday life. Deep thinking is the process of sensing objects but understanding a fact, looking for other information that is different from sensory grasping, and looking for connections from the information obtained with the facts that occur and are associated with the concepts underlying these facts. Through the above, it is known that the kinesthetic subject tends to describe it rationally. By connecting the links between the concepts in science with other related concepts, a person will present a unique and different answer. In analytical thinking includes several things such as making a sensible problem solution, researching and evaluating some general conclusions, making a general description of the conclusions based on existing information, and making answers to problems(Art-In \& Tang, 2017; Taleb \& Chadwick, 2016).

Kinesthetic subjects in identifying and evaluating various errors are more likely to solve problems by focusing on specific problems and linking them to the experiences that exist in students' daily lives. This is also driven by high curiosity so that students can explain the related and underlying science concepts. The phenomenon is an effort of every human being that includes several types of skills, curiosity, and analyzing, an object, it takes information that can relate events in everyday life with scientific concepts to be said to be a unified science attitude (Fadly \& Miaturrohmah, 2021). In concluding the kinesthetic subject's main idea remembering a concept, linking the conceptual relationship, and operating the concept (law, science theory), students can explain and detail how to solve problembased problems.

Problem-solving involves a thought process and involves full effort(Halpern et al., 2015). This means that without a thought process and full effort, it is not said to solve a problem and analyze an object, requires information that can relate events in everyday life with scientific concepts to be said as a unified science attitude. In concluding the kinesthetic subject's main idea remembering a concept, linking the 
Fadly, W./ Jambura Physics Journal (2021) Vol. 3 (1): 1-15

conceptual relationship, and operating the concept (law, science theory), students can explain and detail how to solve problem-based problems. This means that without a thought process and full effort, it is not said to solve a problem.

The results of the analysis of the profile of the skill to think analytically in solving problem-based problems based on students learning styles on substance stress material found a chart of the relationship between the skill to think analytically in solving problem-based problems with students' learning styles, and several supporting factors influence it. Indicators of the skill to think analytically in solving problem-based problems. This indicator consists of identifying, differentiated, classifying, connecting, evaluating, and concluding, enabling students to solve problems in the form of problems or problem-solving. Through learners' learning styles that include visual, auditory, and kinesthetic styles, but raises similarities in certain abilities, supported by several factors that support these aspects' achievement, supporting factors such as the family environment, media, learning models, and other external factors. Based on this, it can be described the relationship between aspects of analytical thinking, learning styles, and encouragement from external factors through the following chart illustrates,

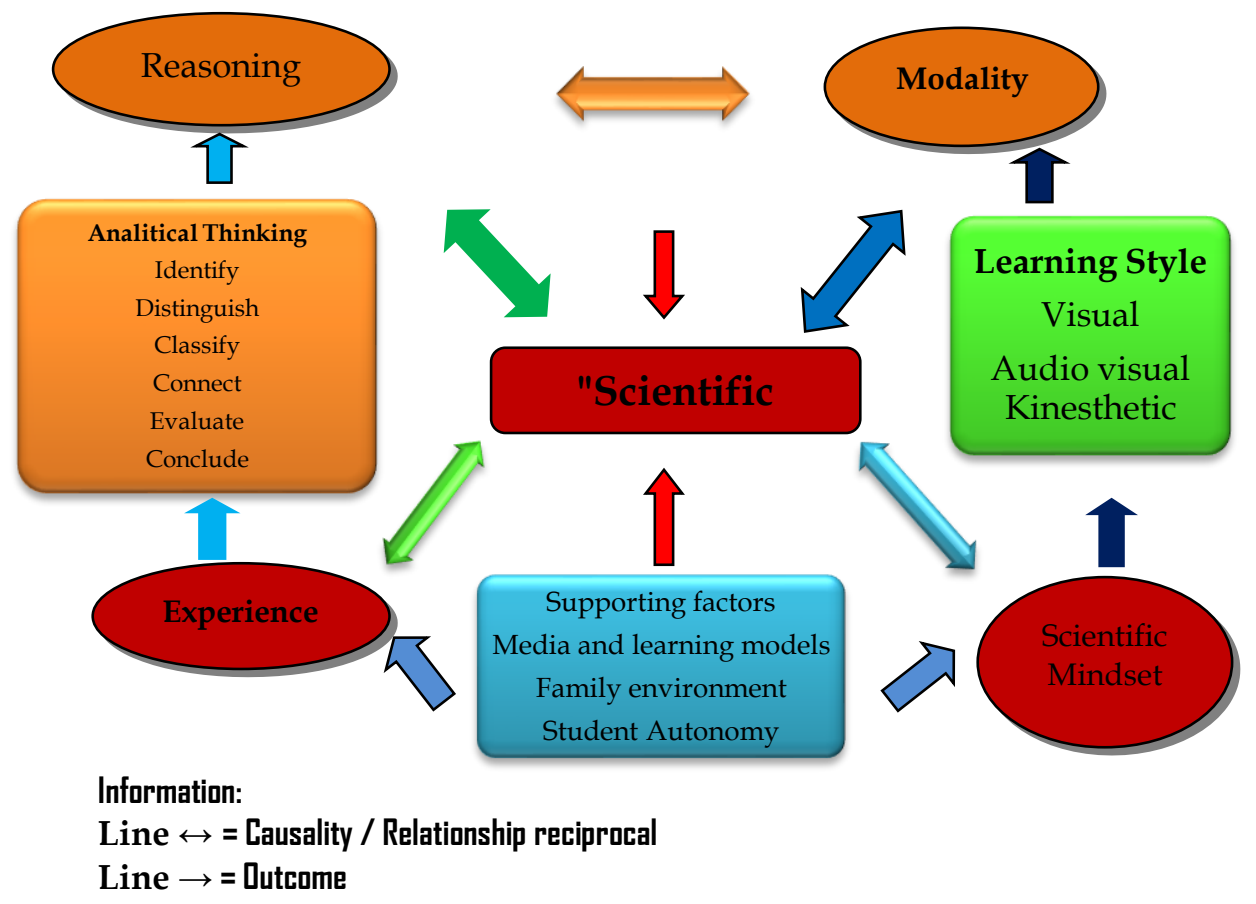

Figure 1. The relationship between analytical thinking, learning styles and supporting factor aspects

Based on the results of the chart analysis, it is known that the relationship between several aspects of research, namely from the aspect of analytical thinking skills, learning styles, and supporting factors, will create new findings as a result of other new aspects. The first time it will be drawn from the aspect of supporting factors, the aspect of supporting factors will provide outcomes of an experience aspect (an experience which later leads to the skill to think analytically) and an aspect of a scientific mindset (which will lead to learning styles of students). Furthermore, the experience chart will provide benefits to the skill to think analytically, namely as a 
Fadly, W./ Jambura Physics Journal (2021) Vol. 3 (1): 1-15

provision in analyzing. When students' analytical thinking skills are good, and the experience is also good, it will provide an outcome in the form of good reasoning abilities.

The reasoning has a reciprocal relationship in the aspect of modality, meaning that these two aspects (reasoning and modality) will influence each other and have their respective roles in the chart(Nandasari \& Yani, 2017). Then in the learning style aspect, there are three types of models, each type will be determined from the form of the participants' scientific mindset so that the scientific mindset is an income from the formation of learning styles from students and the cycle returns to normal again. However, all aspects will provide a research finding that focuses on one aspect of scientific exploration, and scientific exploration has a causal relationship with all aspects shown through the two directions of the arrows in the chart above.

Exploring science results from all activities carried out, interconnected with one another, and as a unit that has roles and supports one another. An explanation of the aspects in the chart above, namely: reasoning is a logical and systematic thought process to find a reason for an answer and evaluate a belief in a statement. In the aspect of the skill to think analytically in solving problem-based problems given to students, in solving these problems students form a pattern of reasoning from real life to the theory that has been studied to find an objective answer.

Experience is an experience that students have, for example, when students solve problem-based problems (problem-solving). Students will find it easier to solve when they already know the concept. It will be easier if they are used to solving problems that are directly faced with the phenomenon in everyday life. Through this experience students will find it easier to formulate the problems they face, experiences will be created from several supporting factors, such as the media and learning models used, the independence of students for example (curiosity, critical and creative), and the family environment, such as parents teaching their children to be independent in doing things at home such as (pumping bicycle tires, help attach clothesline and so on), this will be an experience for the participants (Miaturrohmah \& Fadly, 2020; Spektor-Levy et al., 2013; Zulfa \& Rosyidah, 2020).

This aspect is demonstrated through the following interview excerpts:

"... I am more tired of wearing shoes with high heels because it is difficult to maintain balance, and the load on the surface of the shoes is narrow so that the load will be heavier, compared to those with large surfaces".

This statement proves that students' answers are the result of reasoning, which is the result of their own experiences when wearing heeled shoes. So it can be seen that the reasoning aspect is the outcome of analytical thinking supported by an experience that has been experienced. Several studies have shown that students' skill to understand, assimilate, and process information in learning is influenced by student learning styles and student learning environments (Fadly \& Jannah, 2020; Herman, 2000). Modality is not only limited to a person's way of absorbing information through the senses we have, modality also shows a complex behavior of learners, namely: showing a sense of certainty, skill, skill, and skill. And the scientific mindset is a form or direction of thinking of students who are supported by these factors so that the maximum supporting factors and the amount of experience from 
Fadly, W./ Jambura Physics Journal (2021) Vol. 3 (1): 1-15

students, of course, will create something new, or known as scientific exploration. A mindset can be shown by analyzing the questions given by students. Evidenced by the following interview expert The aspect of modality, which is income from of a mindset can be demonstrated by analyzing students' questions. Evidenced by the following interview excerpt: The aspect of modality, which is income from the form of a mindset, can be demonstrated by analyzing students' questions (Nandasari \& Yani, 2017). Evidenced by the following interview excerpt:

"..... The first time I saw the question number first, then saw the picture, read and examined the problem, and then answered the problem. By using the formula $P=F / A$, and it is known that the result metal $b$ has a more significant pressure than other metals, this is related to the cross-sectional area, namely that the smaller the cross-sectional area, the greater the resulting pressure".

The interview above shows a skill that students already possess which is also the result of their scientific mindset that has been formed. This proves that students' abilities are an initial modality that is influenced by their mindset and is supported by supporting factors. It shows that the plot in the completion is good so that it can answer questions correctly. Students tend to have different modalities (visual, audiovisual, and kinesthetic), and when solving problem-solving, students tend to use the modality seen through their activities in answering problem-solving questions with different thoughts (Nandasari \& Yani, 2017).

Exploration of science is something that is done to gain new knowledge. It refers to the experience of solving and understanding a phenomenon of a problem. The sains exploration aspect is a combination of 4 aspects that arise from the relationship between analytical thinking skills, learning styles and supported by external factors. This is shown through the following interview excerpt:

"...... I get more tired when I wear heeled shoes. When wearing shoes with heels, the bodyweight will be supported by the soles of the front feet because when wearing heeled shoes, our feet will experience a tilt or be on an oblique position, so that only the forelegs support the weight of the body, so that the soles of the forefoots will get a lot of pressure from the load that is supported, so even though the weight is small, they will still feel tired, because when someone uses large heeled shoes the pressure will adjust to the load of the person using it, so it is still directly proportional to the feeling of fatigue that is felt.

The description above follows the research findings that the aspects of reasoning, experience, scientific thought patterns, and modalities arise from the relationship between analytical thinking skills and learning styles from participants and are strengthened by encouraging factors so that the four aspects will lead to activity: new, a namely scientific exploration. Exploration is a study that explores the causes or things that are initial and which affect the occurrence of things to explore new knowledge in new ways and can be a solution or a way out of a problem (Setyawan, 2017).

In the aspect of analytical thinking skills and student learning styles, the most interesting thing is the reasoning that integrates with the modalities of students, meaning that reasoning will be better if students have good modalities. Students who 
Fadly, W./ Jambura Physics Journal (2021) Vol. 3 (1): 1-15

have the kinesthetic type meet all reasoning skill indicators at the stage of understanding the problem until the stage of completion. This means that modality becomes the basic point in achieving reasoning. The reasoning is the outcome of analytical thinking. Besides the aspects that arise from analytical skills and supporting factors experience, Gestalt psychological theory in solving a problem requires an insight, the success of gaining insight after going through the organization of perceptions of the overall problem situation (pattern) to be overcome is found through an experience (Arends, 2012; Slavin, 2019).

In an aspect of learning styles and supporting factors, it emerges from the scientific mindset. The scientific mindset is created because of a person's point of view. This perspective is created through someone's experience because the experience will create a direction or pattern in which a person will move forward in a design. This scientific thought is usually carried out by observations of previous events and then formulated to problems to be discussed, such as when a student who has solved the problem of building space and who has never faced the problem of building space, of course, can be ascertained that students who have solved it will be more good at solving these problems (Herman, 2000; Yoon et al., 2014).

\section{Conclusions}

The profile of students' analytical thinking skills according to their learning style. In visual style students in making solutions and problem-solving strategies tend to be in the form of writing and then explained through direct explanations in more detail, visual learners link the concept and the problem given by providing general answers, in answering the questions of students restate the problem correctly in a mathematical form or model written on the answer sheet. Students of audiovisual style in making solutions and problem-solving strategies form simpler patterns with generalized reasoning patterns. Students also tend to mention the conclusions of the problem by relating to the concept appropriately, and choosing the concept of pressure correctly In the kinesthetic style, kinesthetic style students' analytical thinking skills in making solutions and problem-solving strategies are more likely to apply different (unique) concepts, however, still has a relationship with the problem. Apart from these profiles, it can also be seen that-the relationship between analytical thinking skills and learning styles. The patterns formed from these linkages can be realized in scientific exploration activities, which include aspects of experience, reasoning, modality, and students' mindset.

\section{References}

Al-Balushi, S. M., \& Coll, R. K. (2013). Exploring Verbal, Visual, and Schematic Learners' Static and Dynamic Mental Images of Scientific Species and Processes in Relation to Their Spatial Ability. International Journal of Science Education, 35(3), 460-489. https:/ / doi.org/10.1080/09500693.2012.760210

Arends, R. (2012). Learning to teach. In Connect, learn, succeed CN - LB1025.3 .A74 2012 (9th ed). McGraw-Hill.

https://hasanahummi.files.wordpress.com/2017/04/connect-learn-succeed- 
richard-arends-learning-to-teach-McGraw-hill-2012.pdf

Art-In, S., \& Tang, K. N. (2017). Development of analytical thinking skills among the university students. Turkish Online Journal of Educational Technology, 2017 (October Special Issue INTE), 862-869.

Cano, F., García, Á., Berbén, A. B. G., \& Justicia, F. (2014). Science Learning: A path analysis of its links with reading comprehension, question-asking in class, and science achievement. International Journal of Science Education, 36(10), 1710-1732. https://doi.org/10.1080/09500693.2013.876678

Dierks, P. O., Höffler, T. N., Blankenburg, J. S., Peters, H., \& Parchmann, I. (2016). Interest in science: a RIASEC-based analysis of students' interests. International Journal of Science Education, 38(2), 238-258. https:/ / doi.org/10.1080/09500693.2016.1138337

Fadly, W., \& Jannah, F. (2020). Diagnostic Skill of Internalization-Interconnection Qur'ani With Science in Three Levels of Madrasah. Cendekia: Jurnal Kependidikan Dan Kemasyarakatan, 18(2), 267-289.

Fadly, W., \& Miaturrohmah, M. (2021). Arguing Skillfully with Argument-Driven Inquiry Science Textbooks. 9(1), 119-138. https:// doi.org/10.24815/jpsi.v9i1.18630

Fraenkel, J. R., \& Wallen, N. E. (2012). How To Design And Evaluate Research In Education 8th Ed.

http://archive.org/details/HowToDesignAndEvaluateResearchInEducation8th Ed

Gustiati, M. (2017). Profil kemampuan penalaran matematis dalam pemecahan masalah ditinjau dari kecerdasan emosional dan gaya belajar siswa. Pascasarjana.

Halpern, D., Oh, K. E., Tremaine, M., Chiang, J., Bemis, K., \& Silver, D. (2015). Learning Visualization Strategies: A qualitative investigation. International Journal of Science Education, 37(18), 3038-3065. https://doi.org/10.1080/09500693.2015.1116128

Henderson, J. B., MacPherson, A., Osborne, J., \& Wild, A. (2015). Beyond Construction: Five arguments for the role and value of critique in learning science. International Journal of Science Education, 37(10), 1668-1697. https://doi.org/10.1080/09500693.2015.1043598

Herman, T. (2000). Strategi pemecahan masalah (problem solving) dalam pembelajaran matematika. Makalah. Tidak Diterbitkan.

Jones, M. G., Gardner, G. E., Robertson, L., \& Robert, S. (2013). Science Professional Learning Communities: Beyond a singular view of teacher professional 
Fadly, W./ Jambura Physics Journal (2021) Vol. 3 (1): 1-15

development. International Journal of Science Education, 35(10), 1756-1774. https://doi.org/10.1080/09500693.2013.791957

Lopez, J. E., \& Tancinco, N. P. (2016). Students' analytical thinking skills and teachers 'instructional practices in Algebra in selected state universities and colleges. International Journal of Engineering Sciences \& Research Technology, 3(6), 681-697. https://doi.org/10.1089/15258160260090942

Marini, M. R. (2014). Analisis kemampuan berpikir analitis siswa dengan gaya belajar tipe investigatif dalam pemecahan masalah matematika. Artikel Ilmiah, 1-10.

Miaturrohmah, M., \& Fadly, W. (2020). Looking At a Portrait of Student Argumentation Skills on the Concept of Inheritance (21St Century Skills Study). INSECTA: Integrative Science Education and Teaching Activity Journal, 1(1), 17. https://doi.org/10.21154/insecta.v1i1.2056

Moleong, L. J., \& Surjaman, T. (1991). Metodologi penelitian kualitatif. Penerbit PT Remaja Rosdakarya.

Nandasari, W. I., \& Yani, A. (2017). Pembelajaran Problem Posing Berstruktur Modalitas Siswa untuk Mengembangkan Keterampilan Problem Solving di SMP. Jurnal Pendidikan Dan Pembelajaran Khatulistiwa, 6(2), 1-16.

Nugraha, A. J., Suyitno, H., \& Susilaningsih, E. (2017). Analisis kemampuan berpikir kritis ditinjau dari keterampilan proses sains dan motivasi belajar melalui model pbl. Journal of Primary Education, 6(1), 35-43.

Permana, Y., \& Sumarmo, U. (2007). Mengembangkan kemampuan penalaran dan koneksi matematik siswa SMA melalui pembelajaran berbasis masalah. Educationist, 1(2), 116-123.

Sari, A. K. (2014). Analisis Karakteristik Gaya Belajar VAK (Visual, Auditorial, Kinestetik) Mahasiswa Pendidikan Informatika Angkatan 2014. Edutic-Scientific Journal of Informatics Education, 1(1).

Setyawan, D. (2017). Eksplorasi Proses Konstruksi Pengetahuan Materi Bangun Ruang Siswa dengan Gaya Berpikir Acak dan Kemampuan Keruangan Level Rotasi Mental. Jurnal Ecosystem, 17(1), 643-652.

Shen, J., Sung, S., \& Zhang, D. (2015). Toward an Analytic Framework of Interdisciplinary Reasoning and Communication (IRC) Processes in Science. International Journal of Science Education, 37(17), 2809-2835. https:/ / doi.org/10.1080/09500693.2015.1106026

Slavin, R. E. (2019). Educational psychology: Theory and practice. Allyn and Bacon. http://www.dphu.org/uploads/attachements/books/books_4778_0.pdf 
Fadly, W./ Jambura Physics Journal (2021) Vol. 3 (1): 1-15

Spektor-Levy, O., Baruch, Y. K., \& Mevarech, Z. (2013). Science and Scientific Curiosity in Pre-school-The teacher's point of view. International Journal of Science Education, 35(13), 2226-2253. https://doi.org/10.1080/09500693.2011.631608

Taleb, H., \& Chadwick, C. (2016). Enhancing Student Critical and Analytical Thinking Skills At a Higher Education Level in Developing Countries : Case Study of the British University in Dubai. Journal of Educational and Instructional Studies in the World, 6(February), 67-77.

Thomas, G. P. (2013). Changing the Metacognitive Orientation of a Classroom Environment to Stimulate Metacognitive Reflection Regarding the Nature of Physics Learning. International Journal of Science Education, 35(7), 1183-1207. https://doi.org/10.1080/09500693.2013.778438

Wahyuni, Y. (2017). Identifikasi Gaya Belajar (Visual, Auditorial, Kinestetik) Mahasiswa Pendidikan Matematika Universitas Bung Hatta. JPPM (Jurnal Penelitian Dan Pembelajaran Matematika), 10(2).

Winarni, J., Zubaidah, S., \& H, S. K. (2016). STEM: apa, mengapa, dan bagaimana. In Prosiding Seminar Nasional Pendidikan IPA Pascasarjana UM (Vol. 1, pp. 976-984).

Winarti. (2015). Profil Kemampuan Berpikir Analisis Dan Evaluasi Mahasiswadalam Mengerjakan Soal Konsep Kalor. Jurnal Inovasi Dan Pembelajaran Fisika, 2(1), 1924. https://doi.org/10.36706/jipf.v2i1.2350

Yoon, H., Woo, A. J., Treagust, D., \& Chandrasegaran, A. L. (2014). The Efficacy of Problem-based Learning in an Analytical Laboratory Course for Pre-service Chemistry Teachers. International Journal of Science Education, 36(1), 79-102. https://doi.org/10.1080/09500693.2012.727041

Zulfa, A. R., \& Rosyidah, Z. (2020). Analysis of Communication Skills of Junior High School Students on Classification of Living Things Topic. INSECTA: Integrative Science Education and Teaching Activity Journal, 1(1), 78-92. 